\title{
The Media in the Service of ISIS Propaganda War
}

\author{
Daleen Al lbrahim \\ Wuhan University, China. \\ daleenalibrahim@gmail.com \\ Yibin Shi \\ Wuhan University, China. \\ chuanbo2005@126.com
}

\begin{abstract}
The Islamic State of Iraq and Syria (ISIS) is a unique media phenomenon that benefited greatly from the tremendous technological developments in the world in recent years, the thing which called for Western and other countries to take many measures to reduce the risk of its widespread fame. This study discusses how ISIS uses the media to spread their propaganda, especially the exploitation of modern communication technology. It also examines an essential aspect of the way the mainstream media deal with ISIS media, showing how we could respond to the narrative of ISIS in the era of new media technology. The study concludes that ISIS relies on all media outlets from the mainstream media to social media platforms (e.g. Facebook and Twitter) to propagate their barbarous ideas. However, the mainstream media and social networks have taken norms against terrorist and extremist groups, besides defining rules of employment that prohibit the use of their services to promote terrorist activities.
\end{abstract}

Keywords: The Islamic State, terrorism, new media, social media, ISIS' propaganda, mainstream media

\section{INTRODUCTION}

The Islamic State of Iraq and Syria (ISIS), a political and military organization led by Abu Baqr al-Baghdadi, was based in Iraq, Syria and some parts of Sinai. It holds a radical interpretation of Islam as a political philosophy (Smith, Burke, de Leiuen, \& Jackson, 2016). The name was changed by Western countries from the Islamic State of Iraq (ISI) to the Islamic State of Iraq and Syria or the Islamic State of Iraq and al-Sham (ISIS) (Smith, Burke, de Leiuen, \& Jackson, 2016; Steindal, 2015). Then it was changed to Islamic State in Iraq and the Levant (ISIL), and the latest use is Islamic State (IS), or as it is known by Arabs "Daesh" (Edwards, 2015; Steindal, 2015; Greene, 2015).

The terrorist experts, politicians and researchers identify the Islamic State as a terrorist group seeking to establish a "Caliphate" that covers some countries in the Middle East (Satti, 
2015). It is a non-state actor that has emerged as a direct consequence of the deteriorating political and security situation in both Syria and Iraq (Edwards, 2015).

The outbreak of Syrian civil war in 2011 offered a valuable opportunity for the Islamic State of Iraq (ISI) to spread. In August 2011, ISI's leader Abu Bakr al-Baghdadi had sent a group to Syria to establish a branch of al-Qaeda there, which soon called itself (The Nusra Front). By 2013, however, a split developed between the Nusra Front and ISI over the ultimate leadership of the global jihadist movement (Haykel, 2016). After that Al-Raqqa in eastern Syria was conquered in late 2013, and Mosul, Iraq's second largest city, fell in June 2014 (Haykel, 2016). Following the announcement of a Caliphate in July 2014, the Islamic State in Iraq and Syria (ISIS) spread through vast areas of Iraq and Syria (Perry \& Long, 2016). In a short period, ISIS was able to attract and recruit some youth elements as members to join it both from Iraq and Syria and from some Asian and European countries as well, the thing which raised many questions about why some young people were attracted to the organization.

It can be said that ISIS is a relatively modern organization that could develop recruitment strategies and mobilization of youth groups through benefiting from the recent tremendous technological developments in the world (Awan, 2017; Al Labban, 2016). Simone Molin Friis (2017) believes that the ISIS was able to influence not only because of the regional conquests and organizational development, but more importantly because of the symbolic power of expression and the global scene of violence that the group has created in people's minds through exploiting media power, especially new and social media. Thus, by presenting brutal violence with the serviceof media, ISIS managed to capture the imagination of a global audience, provoke strong reactions, and position itself at the centre of contemporary security debates.

\section{HOW DOES ISIS EXPLOIT MEDIA TO SPREAD ITS PROPAGANDA?}

As it is clear, ISIS is not the first terrorist group relying on the visual media to spread its goals globally (Friis, 2017; Yeung, 2015). However, scholars such as Kamolnick (2017) and Gartenstein-Ross, Fritz, Moreng and Barr (2015) see that ISIS has gone beyond Al Qaida and other organizations in employing media to serve their interests.

Since the founding of ISIS, it has been able to produce its propaganda amazingly through releases: long videos, global magazines, radio programs and Smartphone applications. The most effective medium has been delivering the content in many languages such as English, Arabic, Russian, Urdu, Turkish and even Hebrew (Williams, 2016). Moreover, to assert its authority and to promote fear, among both Muslims and in the West, ISIS has published a dramatic spectacle in the videos of beheadings, torture and mass murders (Friis, 2017; Perry \& Long, 2016; Friis, 2015; Yeung, 2015).

It seems that the power of ISIS is primarily in using high technology to deliver its message (Lieberman, 2017; Pellerin, 2016). Since we leave in the age of the picture; ISIS uses images to amplify its force and to send its message shockingly. The technological skills of ISIS are not only reflected in the way in which it disseminates its material, but also in how it produces content in an effective visual way (Friis. 2017; Lieberman, 2017; Yeung, 2015). ISIS has recruited skilled media professionals from the West to assist in the dissemination of its propaganda in multiple languages (Williams, 2016; Pellerin, 2016). 
Moreover, ISIS' strategy does not depend only on image but extends to the visual and audio effects which carry many brutal messages that are beyond belief. In fact, ISIS produces a large number of videos that mimic Hollywood-style special effects and add exciting novels to capture the viewer's attention and secure media coverage (Lieberman, 2017; Williams, 2016; Veilleux-Lepage, 2016; Pellerin, 2016). The video production company "Al-Hayat Media Center" has produced hundreds of propaganda videos for ISIS using cinematic style (e.g. Flames of war, clashing of swords, and healing of the believer's chest), unlike videos of terrorist groups with poorly produced films that include boring and long speeches of terrorist leaders (Williams, 2016; Veilleux-Lepage, 2016; Al-Qarawee, 2015).

The primary media arms of ISIS, "Al-Hayat Media Center" (Lieberman, 2017; Siboni, Cohen, \& Koren, 2015), has published the ISIS' online magazine "Dabiq" since 2014 and made it available in several languages, such as Turkish, English, French, and German (Monaci, 2017; Al-Qarawee, 2015). It has an essential aim of reaching people in the West for recruiting (Pellerin, 2016). "Al-Furqan" is also affiliated to ISIS, serving as the official media arm of ISIS and its leaders (Siboni, Cohen, \& Koren, 2015; Al-Qarawee, 2015). As researchers mentioned, through Al-Furqan, ISIS has published videos of beheading, crucifixion, burning, drowning hostages, executions carried out by children, the destruction of prisoners by tanks and other forms of violence (Friis, 2017). ISIS also owns the "Shumukh Al-Islam" network, "Al-I'tisaam", "Ajnad Media Foundations", and the "A'maq News Agency" (Williams, 2016, p. 3; Al-Qarawee, 2015) to be also a formal trumpet to publish official statements to the jihadists (Al Labban, 2016).

Besides exploiting the main media, ISIS has worked to promote its propaganda through a sophisticated understanding of new media technology (Friis, 2017). Increasingly, ISIS' terrorists are using the Internet for various purposes, including fundraising, advertising and training. Many websites provide user guides on topics such as explosive materials, recruitment and mobilization, coordination and communication between members and supporters, planning terrorist attacks, and disinformation (Lieberman, 2017; Awan, 2017; Alsyfy, 2016; Yeung, 2015; Al-Qarawee, 2015).

The number of accounts of ISIS was about 12 accounts on the Internet, launched on the Russian social network called "VK", which is not much different from Facebook. It is the first in Europe, with more than 100 million active members. ISIS has selected this website, which cannot be monitored or tracked through the United States and its security services, in order to post state news moment by moment, publish ceremonies and decrees coming from the Caliph in Arabic and English (Al Labban, 2016).

ISIS is the first terrorist organization exploits the high capabilities of social media, as the use of social media is seamlessly integrated with the strategies of ISIS (Lieberman, 2017; Smith, Burke, de Leiuen, Jackson, 2016; Al-Qarawee, 2015). ISIS benefits from social media according to recruit individuals, send friendship requests, upload videos, launch games, etc. (Alsyfy, 2016). ISIS also uses social media to obtain information about enemies by monitoring soldiers' activities on social media, which allow the rapid exchange of information among members about explosives, targets, etc. (Lieberman, 2017; Awan, 2017; Alsyfy, 2016).

The ISIS' jihadists apply all social media apps and file-sharing platforms to promote their propaganda, most prominently Ask.fm, Facebook, Instagram, WhatsApp, PalTalk, Kik, Viper, JustPaste.it, and Tumblr. They also use encryption software, such as TOR, in communications with journalists to obscure their location information (Lieberman, 2017; Klausen, 2015; Smith, 
Burke, de Leiuen, and Jackson, 2016; Yeung, 2015; Al-Qarawee, 2015). With the expanding role of social media, ISIS has used those tools, especially Facebook, Twitter and YouTube to attract and recruit young people to join it. ISIS is relying on the mechanism of continuous dissemination, not only for the statements issued by the organization but also to the most brutal videos in an attempt to send a message to viewers, including young people. All that to double the potential of the organization, which is able, by that vision, to confront some of the regular traditional armies in the Arab region like Iraqi army (Awan, 2017; Al Labban, 2016; Satti, 2015; Yeung, 2015; Al-Qarawee, 2015).

ISIS has also developed a free electronic application called Fajr Al Bashaer (The Dawn of Glad Tidings), which publishes tweets automatically on the accounts of subscribers (Awan, 2017; Pellerin, 2016). About 44,000 tweets were published in one day during clashes in Iraq. Among the widely circulated tweets is a picture of militant jihadists standing under the banner of ISIS in the Iraqi city Al Mosul with the comment, They're coming Baghdad (Pellerin, 2016).

The unique ability of ISIS has been identified to benefit from non-affiliated sympathizers who merely retweet their propaganda, a critical mechanism used in stimulating recruitment and justifying attacks. Then, small groups of social media users are used as potential recruiters and their conversations are moved to safer online platforms (Awan, 2017; Pellerin, 2016; Klausen, 2015; Al-Qarawee, 2015). Thus, although Twitter may not be the place where recruitment ends, increasing evidence suggests that recognized recruitment patterns start on Twitter (Benigni, Joseph, \& Carley, 2017).

By studying statements and texts of individual terrorists and extremist organizations on the social media network, Sara Monaci (2017) distinguishes between four distinct narratives of terrorists, which apply to the objectives of the ISIS propaganda in social media:

- Political narratives: These can be identified on topics such as the crimes of the West and their agents, the global repression of certain minorities and the unequal distribution of income, welfare or land. Violent extremists succeed in telling a politically persuasive story, and often do not aspire to be part of the political solution themselves.

- Moral narrative: Extremists use it through a constant vision of concepts such as liberal democracy, freedom of expression, gender equality, the untenable Western ideals, moral deterioration that led to the substitution of God's sovereignty and laws by the people, indifference, neglect of the family, the destruction of young people through the distribution of drugs, alcohol, etc.

- Religious discourse: This is used to reinforce the perception that fighting against the "immoral" West is a just cause. The jihadists use a convincing theological argument that sanctions the use of violence against the enemies of Islam - they claim that they are universally valid and an individual duty for every Muslim to prove himself a real Muslim.

- The heroic social narrative: The jihadists use this type of narrative to exploit the feelings of social exclusion among young men and women in a celebrity's culture. They struggle against the West to the fullest of craving for adventure, heroism, magic, and admiration by emphasizing romantic concepts of fraternity and exciting life in the camps. 
Therefore, researchers believe that the actual purpose of ISIS' violence narrative is the viewer who exposes to different forms of visual media. The direct victim is not the ultimate goal of violence; the victim is just a carrier of the message (Friis, 2017). Thus, coordinated executions in the videos of ISIS are not random atrocities, but rather manifestations of a distinct type of political violence based on the visual impact of suffering and death on the target audience (Friis, 2017; Perry \& Long, 2016). ISIS is aware of the effect of the picture as an essential weapon in a psychological war. It has succeeded in establishing a mental image in the world as an exceptional terrorist entity in the brutality.

\section{HOW DO THE MAINSTREAM MEDIA DEAL WITH ISIS' MEDIA?}

Klausen (2015) sees the Internet as a valuable gift for terrorists; whereas, the social media radically has changed the balance of power. Terrorists are no longer dependent on mainstream media (Klausen, 2015), and has abolished the role of journalists as main channels for spreading the message (Williams, 2016; Klausen, 2015).

On the contrary, mainstream media are now dependent on social media run by terrorists (Klausen, 2015). The mainstream media have become more dependent on videos and images produced and issued by ISIS (Williams, 2016). ISIS has succeeded in employing the mainstream media as a significant publisher of its products to achieve its objectives, as mainstream media often rely on the outcomes of ISIS as their primary source of information (Friis, 2017). For example, some television stations and electronic media deal with the $A^{\prime} m a q$ News Agency, which belongs to ISIS, as it deals with the high credibility news agencies, impartially transmit news and information that it has not been able to prove from other sources. So, ISIS has been able to exert considerable control over the way it is depicted (Williams, 2016).

Worse still, mainstream media outlets have been involved in transferring news from some Facebook pages of activists and other anonymous people and integrating them into the news cycle, eventually becoming "clean" news and being translated into known sources. Williams (2016) and Klausen (2015) have argued that the danger of sending journalists to Syria and Iraq has made the mainstream media more dependent on materials produced by ISIS. The mainstream media often use the ISIS' propaganda in an unintended manner in ways that serve the goals of ISIS. As a result, the mainstream media have become more vulnerable to campaigns and tactics of deception and misinformation (Williams, 2016; Klausen, 2015). The heavy coverage for this terrorist group assists in achieving a status it does not deserve and supports it in recruiting new members and spreading fear in its enemy (Williams, 2016).

Sherif Al Labban (2016) notes that the quality and credibility of some news media (e.g. such as CNN, Reuters, France Press, as well as Twitter and Facebook) plays a significant role in disseminating news of the organization faster and in some cases in an exaggerated manner. For example, when the Arabic and international media covered ISIS' possession of "fighter jets" from Al-Jarrah airbase and Altabaqa military airport in Syria, they exaggerated the use of these jets by ISIS jihadists. Although experts in aviation, defense and armaments said that these aircraft represented only junk in the air force market; but their news took more media attention in an exaggerated manner, which in its turn served the propaganda of ISIS. So, as Kraidy (2018, p. 171) concludes, ISIS's systematic social media campaign and its relentless coverage by global media are producing ISIS as a global event chain. 


\section{HOW CAN THE MEDIA RESPOND TO THE NARRATIVE OF ISIS?}

As has been discussed earlier, ISIS is a unique media phenomenon that called for Western and other countries to take many measures to reduce the risk of its widespread fame. While Canada has set itself the goal of eliminating propaganda that supports ISIS and terrorism within its priorities through newly proposed anti-terrorism legislations like Canadian Criminal Code, Bill S-7, Combatting Terrorism Act, Bill C-51, Anti-Terrorism Act 2015, the government of the United States has chosen to confront the actively narrative of ISIS instead. The text of a bill passed by the Senate Intelligence Committee shows that social media companies such as Twitter, Facebook and YouTube would have to notify federal authorities of terrorist activities. The text indicates that such communications include publications of explosives, IEDs and weapons of mass destruction (Reuters, 2015).

The European Union has taken several procedures to remove content that promotes extremism and terrorism from its websites, and has strengthened laws on the publication of these articles. Besides, it has asked social media companies to monitor the content of the Internet. Europol has launched a special task force, the European Union Internet Referral Unit, which is tasked with closing accounts and eliminating extreme propaganda from social media (Williams, 2016).

In 2010, the United Kingdom opened a Counter Terrorism Internet Referral Unit that works with company partners to remove terrorist content from the Internet. The British army has set up a particular unit to conduct a non-lethal war against ISIS with a focus on combating its online narrative (Williams, 2016).

The American researcher on militant groups, Nicholas A. Glavin, wrote an article entitled "Counter ISIS' Narratives on Social Media", through which he called the United States to address the ISIS' propaganda on social networks by exposing its ways of persuading the pioneers of these networks, penetrating chat rooms and developing an e-literacy policy (Glavin, 2015).

Social networks have taken norms against terrorist and extremist groups. In fact, they have defined rules of employment that prohibit the use of their services to promote terrorist activities. For example, Twitter prohibits the publication of direct threats of violence against others and the use of its services for any illegal purposes or for supporting illicit activities (Alsyfy, 2016). In September 2014, anonymous Twitter accounts of the hacker activist group hacktivist announced a massive cyber war against ISIS' digital platforms, including nearly 800 Twitter accounts, 12 Facebook pages and more than 50 emails linked to ISIS (Alsyfy, 2016).

Although there is no obligation to remove or refuse the distribution of the offending content or to discontinue the service, there are difficulties in implementing these norms because it is impossible to control a significant amount of information created by users at the same time. Besides, if an account is subsequently suspended, it is not difficult for them to create another account. There is also no mechanism to validate user data to prosecute if it violates the conditions (Alsyfy, 2016).

As stated by Lauren Williams (2016), ISIS' propaganda challenge of controlling social media is more than just combating it online and cancelling Twitter accounts. Greater efforts should be made to combat their messages through mainstream media as well as social media. The media should be cautious when reporting on the activities of ISIS and stop publishing any material, including all images and videos produced purely for propaganda purposes. In particular, television broadcasting organizations should find alternative means of explaining 
their stories about the activities of ISIS. Thus, the adoption of better norms and practices can enable the mainstream media to end ISIS' propaganda in ways that do not reduce media independence and the public's right to know.

\section{CONCLUSION}

There is no doubt that the phenomenon of ISIS' terrorist media is complex. It has taken a great deal of interest from researchers in various fields (Greene, 2015; Yeung, 2015; Siboni, Cohen, Koren, 2015; Veilleux-Lepage, 2016; Williams, 2016; Pellerin, 2016; Lieberman, 2017; Monaci, 2017; Awan, 2017; Kraidy, 2018) and has received an extensive coverage of Arab and international media. Some believe that an organization that adopts the theories of antiquity is expected to use means of those ages; nevertheless, ISIS has resorted to a professional media policy. The demonstrated capabilities of that group on the media and technology have been apparent. We have found out that it relies on all media outlets from the traditional media to digital platforms to spread its barbarous thoughts to both supporters and opponents. Moreover, in order to build a mental image of itself in the world, and spread terror and panic in the hearts of everyone, ISIS establishes its speech by using the latest and most modern methods of propaganda persuasion and the latest Hollywood techniques (e.g. pictures, symbols, soundtracks, and short videos) that monitor the daily terrorist movements.

Although ISIS has suffered a significant decline in its propaganda as a result of global coalition to defeat ISIS and Iraqi and Syrian regime attacks, it is now taking new steps to reshape the propaganda process (Warrick, 2018). It can be concluded that the war against ISIS is not only a military war but rather a media conflict in the first place, whereas the organization that succeeded in establishing its state in 2014 -which has begun to break down recently- was able to do so only through the media machine. This machine has sometimes been used in recruitment through social networks and websites, and sometimes in the planning of terrorist operations. ISIS has also succeeded in providing attractive content which has attracted tens of thousands of young people, who are looking for a new experience that combines excitement and search for a better reality. In conclusion, to defeat ISIS, we must trump it in terms of the media usage and dominance. Any military victory over ISIS is worthless unless it is accompanied by a media victory and superiority.

\section{AKNOWLEDGEMENT}

The paper is funded by "The National Social Science Fund of China. Funding No: 16CXW034

\section{NOTES}

${ }^{1}$ Daesh is the Arabic language acronym of Islamic State.

2 The fundamental meaning of caliphate "offers an idea of leadership which is about the just ordering of Muslim society according to the will of God". Retrieved from http://time.com/4471463/ caliphate-history/

${ }^{3}$ Dabiq is a town in northern Syria. In the Islamic apocalyptic prophecies, this place will witness the battle of last time between Muslims and the Roman enemies.

4 Canadian Criminal Code is a legislation that control most criminal offences and procedures in Canada. In September 2014, "Criminal Codewas updated to include ISIS 
as a terrorist entity, the Canadian Government ensured that anyone associating with ISIS would face punishment" (Hall, 2015, 30).

5 "Bill S-7, Combatting Terrorism Act was introduced in the Senate by the Honourable Claude Carignan, Deputy Leader of the Government in the Senate, in February 2015 ISIS was listed as a terrorist entity by the Government of Canada. Bill S-7 is a direct legislative response to the foreign fighter phenomenon, making leaving or attempting to leave Canada to partake in terrorist activity or join a terrorist group punishable by a maximum of 10 years imprisonment". (Hall, 2015, 31- 32).

6 Bill C-51, Anti-Terrorism Act 2015 in its third part "criminalizes the promotion or advocacy of terrorism offences. It allows for the seizure and/or deletion of terrorist propaganda." (Hall, 2015, 38- 39).

\section{REFERENCES}

Alsysy, H. (2016). استخدام داعش للإعلام الاجتماعي. Arab Media E Society, 22. Retrieved from https:// www.arabmediasociety.com/daeshs-use-of-social-media-arabic/

Al Labban, S. (2016). قراءة في الاستراتيجية الإعلامية والثقافية لإعلام داعش/Arab Media E Society, 21. Retrieved fron https://www.arabmediasociety.com/a-reading-of-the-media-and-culturalstrategy-of-daesh-arabic/.

Al-Qarawee, H. (2015). The discourse of ISIS: Messages, propaganda and indoctrination. In M. Maggioni \& P. Magri (Eds), Twitter and jihad: the communication strategy of ISIS (pp. 145-165). Milan: The Institute for International Political Studies (ISPI).

Awan, I. (2017). Cyber-Extremism: ISIS and the power of social media. Society, 54(2), 138-149.

Benigni, M. C., Joseph, K., \& Carley, K. M. (2017). Online extremism and the communities that sustain it: Detecting the ISIS supporting community on Twitter. PLOS ONE, 12(12). Retrieved from https://doi.org/10.1371/journal.

Edwards, A. (2015). ISIS and the challenge of Islamist extremism. Political Insight, 6 (1), 12-15.

Friis, S. M. (2015). Beyond anything we have ever seen': beheading videos and the visibility of violence in the war against ISIS. International Affairs, 91(4), 725-746.

Friis. S. M. (2017). 'Behead, burn, crucify, crush': Theorizing the Islamic State's public displays of violence. European Journal of International Relations, 00(0), 1-25.

Gartenstein-Ross, D., Fritz, J., Moreng, B., Barr, N. (2015, December). Islamic State vs. alQaeda, strategic dimensions of a patricidal conflict. New America Report.

Glavin, N. A. (2015), Counter ISIS' narratives on social media. Retrieved from https://www. nytimes.com/roomfordebate/2015/12/06/how-can-america-counter-the-appeal-of-isis/ counter-isis-narratives-on-social-media

Greene, K. J. (2015). ISIS: Trends in terrorist media and propaganda. International Studies Capstone Research Papers. Retrieved from http://digitalcommons.cedarville.edu/ international_studies_capstones/3

Hall, J. (2015). Canadian Foreign Fighters and ISIS. University of Ottawa. Retrieved from https://ruor.uottawa.ca/bitstream/10393/33448/1/HALL\%2C\%20Justine\%2020159.pdf

Haykel, B. (2016). ISIS and al-Qaeda - what are they thinking? Understanding the adversary. The ANNALS of the American Academy of Political and Social Science, 668 (1), 71-81.

Kamolnick, P. (2017). The al-Qaeda organization and the Islamic State organization: History, Doctrine, Modus Operandi, and U.S. policy to degrade and defeat terrorism conducted in the name of Sunni Islam. Strategic Studies Institute and U.S. Army War College Press. 
Retrieved from http://publications.armywarcollege.edu/pubs/3296.pdf

Klausen, J. (2015). Tweeting the Jihad: Social media networks of Western foreign fighters in Syria and Iraq. Studies in Conflict $\mathcal{E}$ Terrorism, 38, 1-22.

Kraidy, M. M. (2018). Terror, territoriality, temporality: Hypermedia events in the age of Islamic State. Television \& New Media, 19(2), 170-176.

Lieberman, A. V. (2017). Terrorism, the internet, and propaganda: A deadly combination. Journal of National Security Law \& Policy, 9(95), 95-124.

Steindal, M. (2015). ISIS totalitarian ideology and discourse: An analysis of the Dabiq magazine discourse. Unpublished master thesis, Norwegian University of Life Sciences, Norway. Retrieved from https://brage.bibsys.no/xmlui/bitstream/handle/11250/2383344/ steindal_2015.pdf

Monaci, S. (2017). Explaining the Islamic State's online media strategy: A trans media approach. International Journal of Communication, 11, 2842-2860.

Pellerin, C. (2016). Communicating terror: An analysis of ISIS communicating strategy. Sciences Po. Retrieved from https:/www.sciencespo.fr/kuwait-program/wp-content/ uploads/2018/05/KSP_Paper_Award_Spring_2016_PELLERIN_Clara.pdf

Perry, S. P., \& Long, J. M. (2016). Why would anyone sell paradise? The Islamic State in Iraq and the making of a martyr. Southern Communication Journal, 81(1), 1-17.

Reuters. (2015). Senate bill would make social media report 'terrorist activity'. Retrieved from https:// www.reuters.com/article/us-usa-congress-socialmedia/senate-bill-would-make-socialmedia-report-terrorist-activity-idUSKCNOPI2CF20150708

Satti, M. (2015). Framing the Islamic State on Al Jazeera English and the BBC websites. Journal of Arab \& Muslim Media Research, 1, 37-53. doi: 10.1386/jammr.8.1.37_1.

Siboni, G., Cohen, D., and Koren, T. (2015). The Islamic State's strategy in cyberspace. Military and Strategic Affairs, 7(1), 127-144.

Smith, C., Burke, H., de Leiuen, C., \& Jackson, G. (2016). The Islamic State's symbolic war: Da'esh's socially mediated terrorism as a threat to cultural heritage. Journal of Social Archaeology, 16(2), 164-188.

Veilleux-Lepage, Y. (2016). Paradigmatic shifts in Jihadism in cyberspace: The emerging role of unaffiliated sympathizers in Islamic State's social media strategy. Journal of Terrorism Research, 7 (1), 36-51.

Warrick, J. (2018, January 22). We are in your home': After losses, ISIS steps up campaign to inspire attacks. The Washington Post. Retrieved from https://www.washingtonpost.com/ world/national-security/we-are-in-your-home-after-losses-isis-steps-up-campaign-to-inspireattacks/2018/01/22/421678a4-f7d6-11e7-a9e3-ab18ce41436a_story.html?noredirect=on\&utm term $=.932210149 \mathrm{a} 82$

Williams, L. (2016). Islamic State propaganda and the mainstream media, Lowy Institute Analyses. 1-24. Retrieved from https://www.files.ethz.ch/isn/196198/islamic-state-propagandawestern-media_0.pdf

Yeung, J. (2015). A critical analysis on ISIS propaganda and social media strategies. Research Gate. Retrieved from https://www.researchgate.net/publication/316146537 